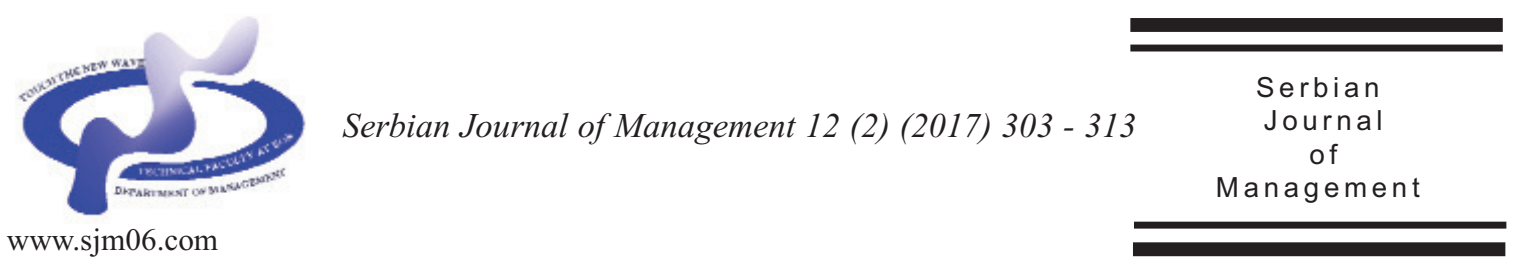

\title{
EMPLOYEE ADAPTATION AS KEY ACTIVITY IN HUMAN RESOURCE MANAGEMENT UPON IMPLEMENTING AND MAINTAINING DESIRED ORGANISATIONAL CULTURE
}

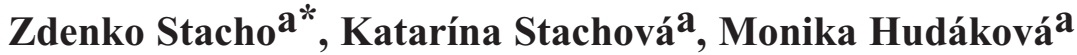 \\ and Renata Stasiak-Betlejewska ${ }^{b}$

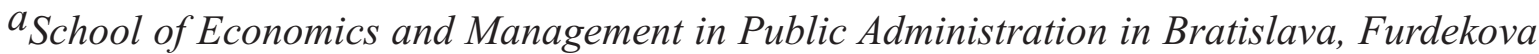 \\ 16, 85104 Bratislava, Slovak Republic \\ ${ }^{b}$ Czestochowa University of Technology, Faculty of Management, Institute of Production \\ Engineering, ul. Dąbrowskiego 69, 42 - 201 Częstochowa, Poland
}

(Received 23 February 2016; accepted 09 February 2017)

\begin{abstract}
In order to achieve the greatest possible equivalence between human resources in a company and desired organisational culture elements declared by a company, it is necessary to interconnect activities within individual functions of human resource management with desired values, attitudes and work behaviour. Such an interconnection is crucial for a positive response of employees to a suitable organisational culture, its embedding in their behaviour and subsequent sharing and spreading of organisational values. This paper will specifically define individual activities related to the adaptation of employees which need to be carried out in this regard. Based on a research conducted between 2011 and 2013, the paper will also define the present state and level of focus of organisations operating in Slovakia on both organisational culture as a whole and organisational culture in the context of employee adaptation.
\end{abstract}

Keywords: organisational culture, human resource management, adaptation of employees, organisations operating in Slovakia

\section{INTRODUCTION}

Organisational culture is something like the personality of a company. Suitable organisational culture should be a set of ways of behaviour and actions of both a company as a whole and its individual employees on their way to achieving strategic objectives of a company as well as personal objectives of employees (Stachová, 2013).

\footnotetext{
* Corresponding author: zdenko.stacho@vsemvs.sk
}

DOI: $10.5937 / \mathrm{sjm} 12-10340$ 
Organisational culture reflects human inclinations in thinking and behaviour and affects both human consciousness and unconsciousness. It strengthens the relationship of people to work, regulates mutual relationships between employees and has a significant impact on the activity of employees (Kachaňáková, 2010). Generally presented and declared organisational culture elements include essential convictions, values and standards outwardly manifested by symbols and artefacts which were designed, discovered or developed in an organisation as a result of successful problem solution, and a group of people bearing organisational culture, in which such a culture is shared (Čambál \& Hoghová, 2008). Authors like Deal and Kennedy (1982), Schein (1999), Cameron and Quinn (2011), Collins and Smith (2006), Kachaňáková (2010), Lukášová (2010), Wei et al. (2010), Cow (2012), Joniaková and Blštáková (2013), Gubíniová and Pajtinková-Bartáková (2014) and Kachaňáková and Stachová (2014) identify with the aforementioned statement in their publications.

With regard to the fact that the bearers of change, respectively bearers of a suitable organisational culture should include all employees of a company, who are expected to share and develop strategically necessary ideas, attitudes and values, it is necessary to focus on organisational culture and human resources simultaneously. Authors like Schein (1999), Collins and Smith (2006), Lukášová (2010), Cow (2012) Urbancová (2012), Kachaňáková (2010), Cambál et al. (2013) and Cagáňová et al. (2010) identify with the aforementioned statement. Such simultaneous focus requires the interconnection of organisational culture and human resource management, declared in their common primary objective, which is, as Kachaňáková (2010) states: "to create conditions for so called positive behaviour of employees in terms of strategic intents and objectives of a company".

Adaptation can generally be understood as a process of active adaptation of people to living conditions and their changes (Remišová, \& Búciová, 2012; Závadský et al., 2015). Social aspects of work, relationships with co-workers and the feeling of belonging in a work environment are important for everybody, as they result in achieving devotion and stability already from the first moment, or, on the contrary, they can result in demotivation, respectively dissatisfaction resulting from the lack of information and worries about coping with work assignments. It is important that the adaptation process is carried out at all three necessary levels. It is necessary at the adaptation level to ensure an introductory training of employees with regard to the whole formation of their abilities according to business needs and to specify definitely the allocation of a new employee at a "right" position (Papula \& Volná, 2012; Dudová, 2014; Kampf et al., 2014). It is necessary at the level of social adaptation to incorporate employees in the existing system of human relationships at workplaces and in companies (Kachaňáková et al., 2011; Maloney \& Stanford, 2011; Stacho \& StasiakBetlejewska, 2014).

At the third level, which is adaptation of employees to organisational culture, it is necessary to help new employees orientate in the existing social standards, standards of acting and behaviour, recognised values as well as status symbols and other means of organisational culture, aiming at employee's identification with them, or adaptation to them, in the greatest possible extent. It is 
necessary at this level to change the view of employees from YOU and YOUR to the attitude ME and MY in the shortest possible time.

The meaning of this activity in relation to organisational culture clearly results from the aforementioned, as within it, new employees become acquainted, respectively do not become acquainted, with all organisational culture elements of a company (from values to the means of organisational culture). This function includes the monitoring and evaluation of whether and to what extent a new employee has "fitted in" a company.

\section{RESEARCH PROCEDURE}

The research was conducted in 2011, 2012 and 2013 from February to May each year. Approximately 350 organisations participated in the research each year, while questionnaire processing was carried out by means of structured interviews with a personnel manager respectively person responsible for human resource management in the given interviewed organisation. The questionnaires were used in a wider research, for example see Stachová and Stacho (2013). The minimum number of 50 employees in an organisation was selected as a stratification criterion for selecting a research sample size, which excluded micro and small organisations from the research on the one hand; however, on the other hand, it significantly increased the likelihood that the organisations will have established a formal system of human resource management. The overall size structure of interviewed organisations is provided in Table 1.

Companies from all sectors of economy were represented in the research each year (Table 2), the research results did not show any significant differences at cross-sector comparison. For the given reason, the research results were evaluated cumulatively, i.e. regardless of sectors companies operate in.

The second stratification criterion was a region of organisation's operation, while the structural composition of the research

Table 1. Size structure of analysed organisations

\begin{tabular}{lccc}
\hline $\begin{array}{l}\text { Number of employees in } \\
\text { organisation }\end{array}$ & $\mathbf{5 0} \mathbf{- 2 4 9}$ & $\mathbf{2 5 0} \mathbf{- 1 , 0 0 0}$ & over 1,000 \\
\hline Number of organisations in 2011 & 221 & 92 & 27 \\
Number of organisations in 2012 & 214 & 102 & 24 \\
Number of organisations in 2013 & 228 & 85 & 27 \\
\hline
\end{tabular}

Source: Own elaboration

Table 2. Percentual share of companies operating in individual sectors

\begin{tabular}{lccc}
\hline \multirow{2}{*}{ Sector / share of companies in \% in year } & \multicolumn{3}{c}{ Share of companies in \% } \\
& $\mathbf{2 0 1 1}$ & $\mathbf{2 0 1 2}$ & $\mathbf{2 0 1 3}$ \\
\hline Industry & $37 \%$ & $40 \%$ & $38 \%$ \\
Agriculture, forestry and fishery & $9 \%$ & $7 \%$ & $10 \%$ \\
Power industry and water management & $3 \%$ & $4 \%$ & $2 \%$ \\
Services & $32 \%$ & $34 \%$ & $35 \%$ \\
Banking, finance and insurance & $5 \%$ & $3 \%$ & $4 \%$ \\
Civil engineering & $11 \%$ & $10 \%$ & $9 \%$ \\
Other & $3 \%$ & $2 \%$ & $2 \%$ \\
TOTAL & $100 \%$ & $100 \%$ & $100 \%$ \\
\hline
\end{tabular}

Source: own research 
sample was based on the data of the Statistical Office of the Slovak Republic.

According to the Statistical Office of the Slovak Republic the number of companies with a number of employees 50 and more was between 3,268 and 3,359 over the period between 2011 and 2013. The regional structure of companies with more than 50 employees in the given years is shown in Table 3.

Determining an optimal research sample of the given basic group of companies, Confidence Level of the research was set at $95 \%$, and Confidence Interval of the research was set at $\mathrm{H}=+/-0.10$. On the grounds of the given criteria an additional, respectively relevant research sample for individual regions of Slovakia was set in the analysed years (see Table 4).

Approximately 500 organisations were included in the research each year, however due to a great extent and the form of data collection only approximately $65 \%$ (350) of questionnaires used to be returned comprehensively completed. Subsequently, 259 organisations, corresponding to the optimal research sample determined on the grounds of stratification criteria, were selected from these organisations.

Key methods used in the conducted research include logical methods, adopting the principles of logic and logical thinking. Particularly the methods of analysis, synthesis, deduction and comparison were applied from this group of methods. Mathematical and statistical methods were also applied in the paper. From software products available on the market, a text editor, a spreadsheet and statistical software were used in the research work, particularly including MS Word 2007, MS Excel 2007 and SPSS 15.0 statistical software for Windows ${ }^{\circledR}$.

\section{RESEARCH FINDINGS}

The part of the research focused on organisational culture was primarily finding out whether managements of the interviewed organisations realised the importance and substantiality of dealing with the creation and maintaining of a suitable organisational culture. Most of the interviewed answered

Table 3. Regional structure of companies with more than 50 employees

\begin{tabular}{ccccc}
\hline Region & Whole Slovakia & Western Slovakia & Central Slovakia & Eastern Slovakia \\
\cline { 2 - 4 } Districts & All districts & $\begin{array}{c}\text { Bratislava, Trnava, } \\
\text { Trenčín, Nitra }\end{array}$ & $\begin{array}{c}\text { Banská Bystrica, } \\
\text { Žilina }\end{array}$ & Košice, Prešov \\
\cline { 2 - 4 } Year & \multicolumn{4}{c}{ Number of companies } \\
\hline $\mathbf{2 0 1 1}$ & 3,359 & 2,061 & 666 & 632 \\
$\mathbf{2 0 1 2}$ & 3,295 & 2,025 & 652 & 618 \\
$\mathbf{2 0 1 3}$ & 3,268 & 2,017 & 645 & 606 \\
\hline
\end{tabular}

Source: data processed according to the Statistical Office of the Slovak Republic

Table 4. Size of the research sample for individual regions of Slovakia

\begin{tabular}{lccc}
\hline Region & Western Slovakia & Central Slovakia & Eastern Slovakia \\
\cline { 2 - 4 } & $\begin{array}{c}\text { Bratislava, Trnava, } \\
\text { Trenčín, Nitra }\end{array}$ & $\begin{array}{c}\text { Banská Bystrica, } \\
\text { Žilina }\end{array}$ & Košice, Prešov \\
\hline $\begin{array}{l}\text { Number of companies over } \\
\text { 2010 - 2014 }\end{array}$ & $2,017-2,061$ & $645-666$ & $606-632$ \\
Size of the research sample & 92 & 84 & 83 \\
\hline Source: Own processing & & &
\end{tabular}


this question affirmatively (Kachaňáková \& Stachová, 2014).

Answers to the first question appear very positive however upon finding out whether the organisations have defined an organisational culture strategy in writing within their organisational strategy, only 21 $\%-33 \%$ of them answered affirmatively (Table 5), while if a clearly and understandably defined organisational culture strategy is absent it is very difficult to derive particular parameters and values of organisational culture from it.

The fact whether organisations have established a system of adapting new employees was primarily analysed within employee allocation. Unfortunately, answers of the interviewed organisations showed that approximately $30 \%$ of them have not established an adaptation system, which implied that these organisations do not realise the importance of adaptation.

An even more negative finding, which can be evaluated even more critically, resulted from question: "Specify the content of the adaptation process of new employees in your organisation." The research showed that organisations declaring that they deal with adaptation actually only deal with it at the level of adaptation to work (Table 6).

A cross table finding out which organisations deal with both social adaptation and adaptation to organisational culture, as all organisations declared that they deal with adaptation to work, was used in order to find out how many organisations out of those declaring that they deal with adaptation deal with it at all three levels (Table 7). The aforementioned showed that only approximately $18-20$ organisations out

Table 5. Spheres in which the analysed organisations have elaborated documents

\begin{tabular}{lccccccccccc}
\hline $\begin{array}{l}\text { Has your organisation } \\
\text { elaborated the following } \\
\text { documents? }\end{array}$ & \multicolumn{2}{c}{$\begin{array}{l}\text { Yes, a document in a } \\
\text { written form in [\%] }\end{array}$} & \multicolumn{2}{c}{$\begin{array}{l}\text { Yes, a document in a } \\
\text { non-written form in } \\
\text { [\%] }\end{array}$} & \multicolumn{3}{c}{ No in [\%] } \\
& $\mathbf{2 0 1 1}$ & $\mathbf{2 0 1 2}$ & $\mathbf{2 0 1 3}$ & $\mathbf{2 0 1 1}$ & $\mathbf{2 0 1 2}$ & $\mathbf{2 0 1 3}$ & $\mathbf{2 0 1 1}$ & $\mathbf{2 0 1 2}$ & $\mathbf{2 0 1 3}$ \\
\hline $\begin{array}{l}\text { Organisational culture } \\
\text { strategy }\end{array}$ & 33 & 29 & 30 & 26 & 21 & 27 & 41 & 50 & 43 \\
\hline
\end{tabular}

Source: Own elaboration

Table 6. Content of adaptation of new employees

\begin{tabular}{lccc}
\hline What is the content of adaptation of new employees? & \multicolumn{3}{c}{ Share of organisations in \% } \\
& $\mathbf{2 0 1 1}$ & $\mathbf{2 0 1 2}$ & $\mathbf{2 0 1 3}$ \\
\hline Adaptation to work & 100 & 100 & 100 \\
Social adaptation & 27 & 25 & 29 \\
Adaptation to organisational culture & 28 & 34 & 32 \\
\hline
\end{tabular}

Source: Own elaboration

Table 7. Cross comparison of organisations dealing with both social adaptation and adaptation to organisational culture

\begin{tabular}{cccc}
\hline \multirow{2}{*}{ The content of adaptation process is: } & \multicolumn{2}{c}{ Adaptation to organisational culture } \\
& & No & Yes \\
\hline \multirow{2}{*}{ Social adaptation [2011] } & No & 63 & 10 \\
& Yes & 9 & 18 \\
Social adaptation [2012] & No & 61 & 14 \\
& Yes & 5 & 20 \\
Social adaptation [2013] & No & 59 & 12 \\
& Yes & 9 & 20 \\
\hline
\end{tabular}

Source: Own elaboration 
of those implementing adaptation deal with adaptation at all three levels. It subsequently shows that only approximately a fifth of organisations out of the whole interviewed sample deal with complex adaptation of newly hired employees.

\section{EVALUATION OF FINDINGS AND DISCUSSION}

The research focused on organisations operating in Slovakia showed that even though $100 \%$ of organisations declare that they realise the substantiality of organisational culture, only $21 \%-33 \%$ of them have defined an organisational culture strategy in writing within their organisational strategy. The given findings also show that although the theory of human resource management deals with three levels of adaptation $30 \%$ of the interviewed organisations have not established a system of adaptation, and only approximately $20 \%$ of organisations deal with the complex adaptation of newly hired employees, i.e. adaptation at all three levels.

The aforementioned clearly shows that it is necessary to focus on both organisational culture and employee adaptation separately and the possibility of their mutual positive influencing. Activities necessary to carry out for this purpose along with their reasons can be described as follows:

Guiding an employee in the adaptation process around the premises of an organisation

Reason: Presentation of the premises of an organisation and related material artefacts is not only necessary from the viewpoint of employee's orientation in an organisation
(Kachaňáková et al., 2011; Armstrong, 2007) but also from the viewpoint of organisational culture, as it first of all includes the employee's recognition of individual artefacts used by an organisation, like the size and placement of logo, colours used in an organisation and its premises; office equipment also reflects how an organisation appreciates its employees, respectively how it takes care of them. Employees also obtain a picture of required, respectively traditional clothing of employees. Due to the fact that like all symbols, also the symbols of material character tend to have a multiple meaning, it is appropriate that new employees are presented their actual meanings (e.g. explanation of a reason why some employees within a single working team sit in an open office and others do not, respectively why some of them wear formal corporate wear while others do not).

\section{Introduction of organisation's organisational structure to an employee in the adaptation process}

Reason: Familiarisation with an organisational structure in terms of organisational culture is crucial from two viewpoints. The viewpoint of an employee and their realisation of their position, respectively status within their organisation as a whole and resulting formal relationships on the one hand (Armstrong, 2007), and familiarisation with an organisational structure, primarily leading representatives, is important from the viewpoint of the image of an organisation on the other hand. (Newly hired employees are frequently asked about their satisfaction, position and management of their organisation by their environment especially shortly after starting at a new position). 
Characteristics of status symbols Presentation of history, strategy, Code of attributed to individual levels of Ethics, the founder and heroes of an management organisation to an employee in the adaptation process

Reason: The need of new employees to become familiar with status symbols results directly from their nature (Hofstede et al., 2010; Schein, 1999; Pfeifer \& Umlaufová; 1993), i.e. the fact that they suggest, respectively should suggest who new employees are encountering, thus suggesting a corresponding way of behaviour and eliminating or reducing possible misunderstandings and conflicts. They at the same time support the identification of employees with their organisation.

Introduction of desirable behaviours and acting to an employee in the adaptation process

Reason: Awareness of causes of individual standards of behaviour and acting in an organisation and their understanding (e.g. formal or informal address; address according to a position, title, surname, name; the position of women / men, etc.) is necessary in order for new employees to adapt. While original employees are key in the adaptation of verbal and nonverbal communication (Ravazzani, 2016; McMilan $\&$ Burnthorne Lopez, 2001). The rules of behaviour are typically non-written however they are a matter of course for employees and their non-fulfilment can even be punished in some cases. Awareness of individual habits, rituals or ceremonials (e.g. birthday or promotion celebrations or welcoming of new employees in a team) and participation in them can make social adaptation of new employees significantly easier.

Reason: Based on knowledge on the history of an organisation or a story related to it, an employee in the adaptation process can fully understand the roots of values supported by an organisation (Armstrong, 2007; Lukášová, 2010; Vybíralová \& Rymeš, 2009; Lašáková et al., 2016). From such stories, legends and myths, employees obtain quite complex information on what attitudes and ways of behaviour are considered to be correct and rewarded by the members of their organisation and which are perceived as inappropriate and unacceptable. If an employee knows "a hero", best personally, it means they know the model of behaviour and the bearer of values in an organisation.

Direct superior has the key impact on adaptation of employees and is primarily responsible for it

Reason: Direct superiors should monitor the quality of an adaptation process of an employee, should participate in it (Blašková, 2011; Lukášová, 2010; Blštáková et al., 2014) whether actively or from the supervisor position, and last but not least, they should be a model for such employees, i.e. their behaviour should correspond to the values, attitudes and ways of behaviour supported by their organisation.

The need of individual approach upon adapting an employee to organisational culture

Reason: The lengths of adaptation of employees to organisational cultures differ. 
They are affected by the ability of an employee to perceive such a type of information and transform it in their behaviour, types of cultures they have experienced before (in both working and private lives), and the level of their own compliance, respectively non-compliance with a new organisational culture.

Familiarisation with organisational culture, its adoption and, ideally, identification with it are especially concerned (Blštáková et al., 2015; Berndová \& Nový, 1994).

As already presented in this part of the paper, activities carried out within employee adaptation have a significant impact on declaring and supporting a desired organisational culture and play a significant role in implementing new and changed suitable organisational culture, supporting the sustainable development of an organisation.

\section{CONCLUSION}

The need to focus on employee adaptation also results from the fact that starting a new job ranks among the most stressful life events. Unfortunately, adaptation is frequently an underestimated sphere of human resource management, although it has a direct and significant impact on the result and success of recruiting and selection of employees, which are typically paid much greater attention (Stýblo et al., 2009). However if a new employee leaves an organisation as a result of unsuccessful adaptation, it always results in significant costs of such an organisation. As Armstrong (2009) points out in his Handbook of Human Resource Management Practice: "In case of losing a specialist, costs can represent up to
$75 \%$ of their yearly pay. Such costs can amount to $50 \%$ of the pay in case of an auxiliary. If fifteen out of a hundred employees with an average yearly pay in the amount of EUR 12,500 leave a company, the overall costs can amount to EUR 90,000, i.e. $7.5 \%$ of the overall labour costs (Armstrong, 2009). There is a need to ensure a quick adaptation to all aspects of a new position. Organisations can thus contribute to stability and satisfaction of employees from their first working day and reduce the level of fluctuation which frequently occurs shortly after starting a new job and results in unnecessary financial costs of an organisation. It is necessary for this purpose to define a desired organisational culture and implement it using individual activities of human resource management, while employee adaptation is specific due to the fact that it is the first function affecting employees upon starting a new job. The paper particularly defined individual activities necessary to carry out for this purpose along with their reasons. Definitions of the given activities cannot be deemed final, however they can be perceived as the key activities upon achieving an effective interconnection of values declared by an organisation and their perception by its individual stakeholders.

\section{Acknowledgement}

This paper represents a partial result of the grant task of the project IGA 2/2010 Human Potential Development in Central and Eastern EU States and IGA 2/2016 Contribution of Selected Attributes of Managerial Work to Creation of Internal Environment Supporting Competitiveness of Companies. 


\section{References}

Armstrong, M. (2007). Human Resource Management. Praha: Grada Publishing. (In Czech).

Armstrong, M. (2009). Handbook of human resource management practice. London: Kogan Page limited.

Berndová, E., \& Nový, I. (1994). Psychology and Sociology in Company Management. Praha: Prospektrum.(In Czech).

Blašková, M. (2011). Development of Human Potential, Motivation, Communication, Harmonization and Decision Making, Žilina: Edis.(In Slovak).

Blštáková, J., Dubcová, G., \& Joniaková, Z. (2014). Use of Corporate Culture in Human Resource Management. Bratislava: Ekonóm.(In Slovak).

Blštáková, J., Gálik, R., Joniaková, Z., \& Tarišková, N. (2015). Changes in Human Resource Management, Human Resource Management in Changes. Bratislava: Ekonóm.(In Slovak).

Cagáňová, D., Čambál, M., \& Weidlichová, L.S. (2010). Intercultural management - trend of contemporary globalized world. Electronics and Electrical Engineering, 6, 51-54.

Cameron, K.S., \& Quinn, R.E. (2011). Diagnosing and Changing Organizational Culture: Based on the Competing Values Framework. Chichester: John Wiley \& Sons.

Collins, C.J., \& Smith, K.G. (2006). Knowledge exchange and combination: The role of human resource practices in the performance of high-technology firms. Academy of Management Journal, 49 (3), 544-560.

Cow, I.H. (2012). The roles of implementation and organizational culture in the HR-performance link. International
Journal of Human Resource Management, 23 (15), 3114-3132.

Čambál, M., Cagáňová, D., Sobrino, D.R.D., \& Koštál, P. (2013). Developing of organisational culture as a presumption of industrial enterprise performance optimization. ICEEP 2013. 2nd International Conference on Energy and Environmental Protection, 3348-3351.

Čambál, M., \& Hoghová, K. (2008). Corporate culture application in enterprises as assumption their long-term prosperity. Annals of DAAAM and Proceedings of DAAAM Symposium. Viedeň: DAAAM International Vienna, 191-192.

Deal, T.E., \& Kennedy, A.A. (1982). Corporate cultures: The rites and rituals of corporate life. New York: Addison - Wesley.

Dudová, I. (2014). Social Protection as the Key Pillar of Social Systems in the European Union. Economic Annals-XXI, 7-8 (1), 36-39.

Gubíniová, K., \& Pajtinková-Bartáková, G. (2014). Customer Experience Management as a New Sourceof Competitive Advantage for Companies. The Proceedings of the 5th International Scientific Conference on Trade, International Business and Tourism „Application of Knowledge in Process of Business Dynamization in Central Europe. Bratislava: Ekonóm, 162-168.

Hofstede, G., Hofstede, G.J., \& Minkov, M. (2010). Cultures and Organizations: Software of the Mind. 3rd Edition, McGrawHill USA.

Joniaková, Z., \& Blštáková, J. (2013). Importance of Organisational Culture in Applying Socially Responsible Business Practice, Volunteering in Slovak Organisations - Research Results. Economic Outlooks, 42 (3), 371-383.(In Slovak).

Kachaňáková, A., \& Stachová, K. (2014). 
Present State of Organisational Culture in Slovakia. Economic Annals-XXI, 3-4 (1), 35-38.

Kachaňáková, A., \& Nachtmanová, O., \& Joniaková, Z. (2011). Human Resource Management. 2nd Ed.. Bratislava: Iura Edition.(In Slovak).

Kachaňáková, A. (2010). Organisational Culture. Bratislava: Iura Edition.(In Slovak).

Kachaňáková, A., Nachtmanová O., \& Joniaková, Z. (2011). Personálny manažment. 2. vydanie, Bratislava: Iura Edition.

Kampf, R., Hitka, M., \& Potkány, M. (2014). Year-On-Year Differences in Motivation of Employees of Slovak Production Plants. Journal Communication, (4), 98-102.(In Slovak).

Lašáková, A., Remišová, A., \& Kirchmayer, Z. (2016). Key Findings on Unethical Leadership in Slovakia. Proceedings of the 1st International Conference Contemporary Issues in Theory and Practice of Management Częstochowa: Wydawnictwo Wydziału Zarządzania Politechniki Częstochowskiej, 252 - 260.

Lukášová, R. (2010). Organisational Culture and Its Change. Praha: Grada Publicshing.(In Czech).

Maloney, K., \& Stanford, P. (2011). The craft of people management. Human Resource Management International Digest, 19 (3), 3-5.

McMilan, A., \& Burnthorne Lopez, T. (2001). Socialization and Acculturation: organizational and Individual Strategies Toward Achieving P-O Fit in a Culturally Diverse Society. The Mid-Atlantic Journal of Business, 37 (1), 19-34.

Papula, J., \& Volná, J. (2012). A Descriptive Analysis of Intellectual Capital Concept Implementation within Slovak Companies. Driving the Economy through
Innovation and Entrepreneurship: Emerging Agenda for Technology Management. Springer, India, 443-451.

Pfeifer, L., \& Umlaufová, M. (1993). Corporate Culture: the Power of Shared Goals, Values and Priorities. Praha: Grada.(In Czech).

Ravazzani, S. (2016). Exploring internal crisis communication in multicultural environments: A study among Danish managers Corporate Communications, 21 (1), 73-88.

Remišová, A., \& Búciová, Z. (2012). Measuring corporate social responsibility towards employees. Journal for East European Management Studies, 17 (3), 27329.

Schein, E.H. (1999). Corporate Culture Surival Guide. San Francisco: Jossey-Bass.

Stacho, Z., \& Stasiak-Betlejewska, R. (2014). Approach of organisations operating in Slovakia to employee's performance evaluation. Economic Annals-XXI, 5-6 (1), 83-87.

Stachová, K., \& Stacho, Z. (2013). Employee Allocation in Slovak Companies. Business: Theory and Practice, 14 (4), 332336.

Stachová, K. (2013). Focus of organisations operating in Slovak on labour relations. Economic Annals-XXI, 5-6 (1), 86-89.

Stýblo, J., Urban, J., \& Vysokajová, M. (2009). Meritum Personalistika 2009-2010. Praha: ASPI.

Urbancová, H. (2012). Results of analysis of organisational culture in organisations in the Czech Republic and Slovak Republic. Acta Universitatis Agriculturae et Silviculturae Mendelianae Brunensis, 60 (7), 433-440.

Vybíralová, L., \& Rymeš, M. (2009). Adaptation of New Employees in 
Organisation - Adaptation Program Methods.

Psychology in Practice, XLIV (3-4), 9-25.

(In Czech).

Wei, J., \& Liu, L., \& Calabrese, A.F. (2010). A cognitive model of intraorganizational knowledge-sharing motivations in the view of cross-culture. International Journal of Information Management, 30 (3), 220-230.

Závadský, J., Hitka, M., \& Potkány, M. (2015). Changes of employee motivation of Slovak enterprises due to global economic crisis. E+M Economics and Management, 18 (1), 57-66. 